\title{
Individual Characteristics, Job Characteristics, and Career Development: A Study on Vocational School Teachers' Satisfaction in Indonesia
}

\author{
Eka Daryanto* \\ Department of Mechanical Engineering Education, Faculty of Engineering, State University of Medan, Medan, Indonesia \\ *Corresponding author: ekadaryanto@unimed.ac.id
}

Received July 24, 2014; Revised August 10, 2014; Accepted August 14, 2014

\begin{abstract}
The job satisfaction is reflected by the affective reaction of an individual on to his/her work related factors. This study explores the relationship between individual characteristics, job characteristics, and career development with job satisfaction of teachers in vocational schools at the Province of North Sumatera, Indonesia. The sample size of this study was obtained using the proportional random sampling which further resulting a total number of 166 teachers who were found having the expected qualification in Mechanical Engineering subject. The hypotheses tests based on the path analysis on the research model revealed that individual characteristics, job characteristics, and career development directly influence job satisfaction. Summary of findings and managerial implications in this study are discussed and put forward.
\end{abstract}

Keywords: individual characteristics, job characteristics, career development, job satisfaction, vocational school teacher's

Cite This Article: Eka Daryanto, "Individual Characteristics, Job Characteristics, and Career Development: A Study on Vocational School Teachers' Satisfaction in Indonesia.” American Journal of Educational Research, vol. 2, no. 8 (2014): 698-702. doi: 10.12691/education-2-8-20.

\section{Introduction}

The job satisfaction has been a pivotal issue in defining the organizational effectiveness. It reflects an individual feelings' towards work that affects both the individual's and organization performances [1]. Hence, the importance of job satisfaction is to motivate organizational members to engage in a kind of behavior that facilitate them in accomplishing the effective performance and productivity with their work [2].

Extant literature suggests that individual job satisfaction is determined by individual characteristic, job characteristic and, career development (see for example [3-10]. The basic premise of the relationship between individual characteristic, job characteristic, and career development with job satisfaction is derived from the trait and factor theory highlighting that the individual is different, and their different capacities may influence their professional occupations [11]. Furthermore, [12] also emphasize that the decision on an occupation from an individual involves the individual desire and expectation on the job thus can make his/her performance become satisfactory. According to Sharf (1992) in [11], traits are determined by individual characteristics and factors are measured by particular expectation required by an individual to achieve his/her successful job performances. In this study, traits are determined by Individual Characteristics (X1). Factors involve Job Characteristics
(X2) and Career Development (X3). And these traits and factors variables' are partially and simultaneously influence Job Satisfaction (Y).

The Individual Characteristics variable is extracted from Hackman and Oldham theory of job characteristics which focusing on personal characteristics that determine their job motivations [7,8]. Previous studies from [4] and [10] reveal that personal characteristics such as age, tenure, gender, educational level, and strong work ethics of an individual are factors that influence individual perceiveness on his/her job satisfaction.

The job characteristics model has been used as a platform for managers in designing jobs that will further satisfy the individual needs [5]. The authors also highlight that job characteristic proxies of the Hackman and Oldham's consisting of autonomy, feedback, skill variety, task identity, and task significance influence the job satisfaction. When employers are suited with the appropriate autonomy, relevant feedback, sufficient skill variety, clear task identity and significance; they will be more firm psychologically. Thus, it is important for employees being occupied with these characteristics as it will affect their perceiveness on the job they are attached with, increasing their responsibility and significantly enhancing their vision on every task they should be working $[8,13]$. Furthermore, the employee will be more satisfied with their job and in turn, it will reduce the employee absenteeism and turnover [5].

The career development involves employees to relate their efforts and the world of their work in fashioning their 
individual work identity [14]. More importantly, the author emphasize the influences on and outcomes of career development are one aspect of socialization as part of a broader process of human development in establishing their existence as a social actor in a professional institution. Put another way, the career development will satisfy the individuals need to be acknowledged within a particular social circumstance. According to [3] and [15], the efforts on employee development contribute to the employee commitment to the organization improving the work productivity and likewise reducing absenteeism and turnover intentions. This study measures the career development based on the argument modified within [3]underlining five major factors. They are: (1) skills development; (2) the development of career maturity; (3) the sufficient knowledge of the individuals on their job; (4) the employees' expectation on their career development, and; (5) emotional responses, and; (6) the relevancy between employees' job, knowledge and skills with their existing career development.

As the educator, a teacher plays an important role in building and developing students' intellectual capacity for their future needs. As this young generation will take the lead to continue the development of the nation, providing them with a high-quality learning process must be taken into consideration by respective bodies in the relevant government structure. Accordingly, the capability of teacher, like any other profession, needs to be continuously upgraded to fit with the most current condition and stakeholders' needs, hence reserving them with a pride as an educator. They will also grant a respect from the stakeholders valuing the teacher's professional job as a cornerstone in the development of a nation.

However, in conducting their educating duties, the teachers face many challenges that influence their efforts in achieving the objectives as earlier mentioned. These challenges are vary among educators which also influenced by particular factors coming from both internal and external conditions of the teacher [16]. More specifically, according to $[17,18,19]$; factors related to the individual psychological condition e.g. individual satisfaction, work condition, pride, and motivation are considered as the determinants for internal factors of individual to maximize their performance. Externally, the teachers' job satisfaction can be reflected in the workplace condition, the social-relationship among the teacher, colleagues and stakeholders, and the provision of jobrelated training that beneficial to maintain teacher's professionalism [20].

The school atmosphere is a unique condition as this is the place where various social interests are integrated. The characteristic of this social interactions also varies across educational levels, from elementary to post-graduate, or educational systems, between general and vocational schools. The arguments to decide which side to be more emphasized have been remained unsolved [21]. For instances, such schools establish their particular role in different societies. In a more details, these authors illustrate that the Germany's system - which involves fully vocational schools as well as those mixing vocational and general education - is highly regarded and consisted over half of the country's upper secondary students. In other countries, however, vocational schools serve as markers of a students' lower socioeconomic status: in Hungary, 54\% of pupils in vocational schools were from the bottom socioeconomic quartile, and in South Korea the figure is $52 \%$. In other countries still, these schools are simply treated as a last port for students who are unable to succeed in more academic environments. As the consequence, these phenomena underline the creativity of the teachers involved within particular educational systems to maintain the broader success of their students.

The Indonesian education system has also faced quite challenges in equipping the students for the successfulness of their further academic paths. In particular, [22] highlight the disproportion number of qualified teachers between secondary schools (including vocational schools) and primary schools as one of the major concern affecting the low quality in the teaching process. Accordingly, [23] emphasizes that the importance on teachers' training to improve teachers' performances to strengthening the teaching and learning process in the actual classrooms. Thus, it will further create the dynamic growth and elevate the knowledge index of local students in the Asian region.

As mentioned earlier, job dissatisfaction among teachers, if not addressed seriously, will further affect the education of the young generation. To the best of the author's knowledge, very limited study have been demonstrated the influence of individual characteristic, job characteristic, and career development on job satisfaction of educational workers, particularly on teachers in the vocational schools. Given the importance of the study, this research aims to analyze the influence of individual characteristic, job characteristic, and career development on the job satisfaction of vocational school teachers in the Province of Sumatera Utara, Indonesia. This study provides significant insights resulted from different type of organization extensifying the important of valuing individual characteristic, job characteristic, and career development to increase job satisfaction of vocational school teachers.

\section{Research Methodology}

\subsection{Research Model and Hypotheses}

As described in the previous section, the basic premise of this study underlines that individual characteristic, job characteristic, and career development on job satisfaction of educational workers, particularly on teachers in the vocational schools. It is derived from the trait and factor theory complemented with the Hackman and Oldham's job characteristic models to further rationalize the research framework of this study. Figure 1 provides a visualization of the relationship between individual characteristic, job characteristic, and career development with job satisfaction.

For the purpose to explain the objective of study set earlier on, this study develops five major hypotheses focusing on the direct relationship between all independent variables (individual characteristics, job characteristics, and career development) and job satisfaction. The overall hypotheses are described as follows:

Hypothesis 1. The individual characteristics positively influence the career development. 
Hypothesis 2. The job characteristics positively influence the career development.

Hypothesis 3. The individual characteristics directly influence the job satisfaction.

Hypothesis 4. The job characteristics directly influence the job satisfaction.

Hypothesis 5. The career development positively influences the job satisfaction.

\subsection{Sample, Data Collection and, Data Analysis}

The sampling frame used in this study was obtained from the Directorate of Elementary Teachers Education [24] focusing on total number of vocational school teachers from state and private vocational schools in the Province of North Sumatera, Indonesia. The population of this study was all teachers who are specialized on the subject of Mechanical Engineering Skills amounting 238 teachers in total. The sample size of this study was gathered based on the proportional random sampling which further resulting a total number of 166 teachers who were found having the expected qualification.

For the purpose of data collection, a questionnaire was developed as the main instrument of this study and distributed to all samples. All of items questioned within the instruments were constructed relevant to research objectives, research questions, and literature review references. The research questionnaires consist of number of Likert-scaled queries following the four variables within this study: individual characteristics, job characteristics, career development, and job satisfaction.

To test the hypotheses, this study used a path analysis method. According to [25], the path analysis approach is suitable to determine the magnitude and significance of the causal relationship between the observed variables (see Figure 1. research framework). The author also underline that the path analysis is more powerful to measure the causal relationship using the mediating variable(s) in a single model without segregating several regression testing. The testing result will estimate the structure of the main path from the independent variable(s) to a dependent variable. The main path will be indicated from a standardized regression coefficient, demonstrating whether there is a direct effect or indirect effect occurred within the research model. A Specht's Goodness of Fit Estimate was used to examine that the model fits the data based upon how well the model reproduces the observed correlation matrix [26]. The author suggests a perfect fit would give a $Q$ of one; less than perfect fits yield $Q$ 's less than one.

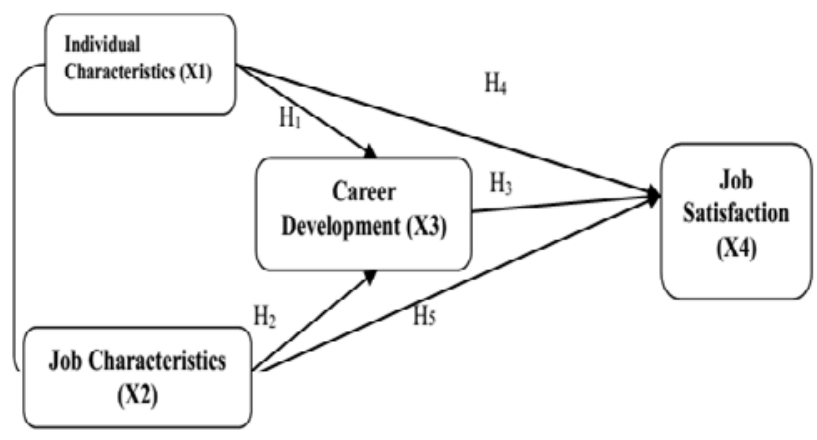

Figure 1. Research Model

\section{Discussion and Analysis}

Based on the theoretical perspective earlier mentioned, this study expects that personal characteristics, job characteristics, and career development are determinant factors of the teachers' job satisfaction in vocational schools in the Province of North Sumatera Utara. Before conducting hypothesis testing, we examined bivariate correlation between two different variables and the results are in-line with the hypothesized relationships (see Table 1). Accordingly, path coefficients in the path analytical method are extracted using Maximum Likelihood (ML) estimation (see Figure 2). In particular, the hypotheses testing were conducted into two structures. Firstly, it examined the partial relationship between individual characteristics and job characteristics with career development $\left(\mathrm{H}_{1}\right.$ and $\left.\mathrm{H}_{2}\right)$. And secondly, it estimated whether there are direct influences between individual characteristics and job characteristics with the mediating effect of career development on job satisfaction $\left(\mathrm{H}_{3}, \mathrm{H}_{4}\right.$, and $\left.\mathrm{H}_{5}\right)$.

Table 1. Path Coefficient and significance levels for initial model

\begin{tabular}{|c|c|c|}
\hline Hypothesis & Correlation Coefficient & Path Coefficient \\
\hline 1 & 0,247 & $0,255^{*}$ \\
\hline 2 & 0,387 & $0,535^{*}$ \\
\hline 3 & 0,389 & $0,134^{*}$ \\
\hline 4 & 0,581 & $0,248^{*}$ \\
\hline 5 & 0,701 & $0,501^{*}$ \\
\hline \multicolumn{2}{|c|}{ *Significance at the 0.001 level (2-tailed) } \\
\hline
\end{tabular}

The results from hypotheses tests reveal that all hypotheses $\left(\mathrm{H}_{1}-\mathrm{H}_{5}\right)$ are accepted. In a more detail, the results indicate that:

1. Individual Characteristics influence Career

Development ( $\mathrm{p}=0.255$, significant at 0.001 )

2. Job Characteristics influence Career Development $(\mathrm{p}=0.535$, significant at 0.001 )

3. Individual Characteristics directly influence Job Satisfaction ( $\mathrm{p}=0.134$, significant at 0.001 )

4. Job Characteristics directly influence Job Satisfaction $(\mathrm{p}=0.134$, significant at 0.001 )

5. Career Development influence Job Satisfaction $(\mathrm{p}=0.501$, significant at 0.001$)$

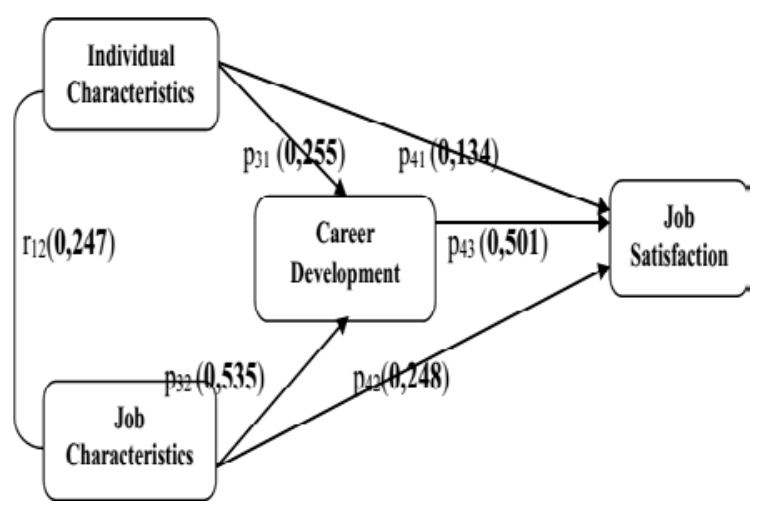

Figure 2. The Result of Path Analysis Model

\section{Concluson and Implication}

In general, the job satisfaction reflects the affective reaction from an individual to both the set of work and work related factors he/she is dealing with [5,27]. The 
results of hypotheses tests indicates that Individual Characteristics Job Characteristics, and Career Development partially (as well as simultaneously) influence Teachers' Job Satisfactions in Vocational Schools in the Province of North Sumatera Utara, Indonesia. In brief, the overall findings also consistent $[4,6,9,10]$ studies highlighting that individual demographic, job characteristics variables and career development variables are considered as significant determinants for employees' job satisfaction. It can be concluded that the larger the gap within the teachers' individual characteristics, job characteristics, and career development; the higher the levels of both job dissatisfaction and yet resulting the higher level of job turnover intentions. Accordingly, the findings of this study confirm the traits and factor theory highlighting the differences in individual preferrences and capacities that influence their perceiveness on the satisfactory of their professional occupations $[11,12]$. Traits are signified from the internal attributes of individual characteristics, and Factors are derived from external drives as reflected in job characteristics and career development.

[3] emphasize that the employee growth and development activities e.g. continuing education courses, tuition reimbursement, career development skills training, opportunities for promotion and internal career advancement, coaching, mentoring, and leadership development programs positively associate with the employees' job satisfaction. In accordance to [15], the efforts put forward employee development has contributed to the employee commitment to the organization, increasing their work productivity and in turn decreasing absenteeism and turnover intentions. Relevant to this study, the career development program facilitates vocational teachers to maximize their individual job satisfaction. It can be done through several activities e.g job transfer to a different location, peer assistance and continuous educational training; to refresh and elevate teachers' knowledge, skills, ability, and experience. Therefore, these programs can increase teachers' satisfaction in committing on to their existing professional job.

The findings from this study also underline the importance on minimizing the gap among personal characteristics and improving the clarity of job assigned relevant to teachers' competencies through proper and continuous career development. Thus, it can maximize teachers' commitment and motivation to achieve the goals of their respective educational institution. Respectively, it will also assist the accomplishment of the general objectives of national educational system.

However, there are several limitations for further concerns in future studies. First, this study was conducted in the Province of North Sumatera and the results may provide particular magnitude to the respective region. The sample size also raised concern for the generalizability issue. Hence, future studies can consider these limitations to provide a stronger justification on the level of magnitude and directions of the relationship among observed variables in a broader scope of analysis.

\section{References}

[1] Locke, E. A. "The Nature and Causes of Job Satisfaction” in Dunnette, M. D. Handbook of Industrial and Organizational Psychology ( $1^{\text {st }}$ Ed.), Chicago, IL: Rand McNally. 1976. 12971349. 1976.
[2] Hong, S. C. Factor influencing job satisfaction of government secondnary school teachers in the district of Petaling, Selangor (Master's thesis, Universiti Putra Malaysia). 1999.

[3] Monis, S. H. and Sreedhara, T. N. "Employee Satisfaction with Career Development Practices: A Comparative Study of Indian and Foreign MNC BPO Firms", Journal of Arts Science \& Commerce, Volume II, Issue 1, 110-122. 2011.

[4] Franěk, M. and Večeřa, J. "Personal Characteristics and Job Satisfaction”, Ekonomika Management. 2010.

[5] Said, N. A. and Munap, R. "Job Characteristics and Job Satisfaction: A Relationship Study on Supervisors Performance", Proceedings of the 2010 IEEE ICMIT, 714-719. 2010.

[6] Samad, S. "The Contribution of Demographic variables: Job Characteristics and Job Satisfaction on Turnover Intentions", Journal of International Management Studies, Volume 1, Number 1, 2-12. 2006.

[7] Hackman, J. R. \& Oldham, G. R.. How Job Characteristics Theory Happened. The Oxford Handbook of Management Theory: The process of theory development, 151-170. 2005.

[8] Hackman J R, Oldham G R. "Development of Job Diagnostic Survey”. Journal of Applied Psychology, Volume 60, 159-170. 1975.

[9] Chen, T.Y., Chang, P. L., and Yeh, C. W. "A Study of Career Needs, Career Development Programs, Job Satisfaction and the Turnover Intentions of R\&D Personnel”, Career Development International, Volume 9, Issue 4, 424 - 437. 2004.

[10] Hickson, C. and Oshagbemi, T. "The Effect of Age on the Satisfaction of Academics with Teaching and Research", International Journal of Social Economics, Volume 26, Issue 4, 1999. 537-544. 2004.

[11] Patton, W. and McMahon, M. Career Development and Systems Theory: Connecting Theory and Practice, Sense Publishers. 2006.

[12] Brown, D. Summary, Comparison \& Critique of the Major Theories in Brown, D., Brooks, L. \& Associates (Eds), Career Choice \& Development. 338-363. San Francisco: Jossey Bass. 1990.

[13] Fried, Y. and Ferris, G.R. "The validity of the job characteristics model: A review and meta-analysis." Personnel Psychology, 40, 287-322. 1987.

[14] Hansen, L.S., "Career Development Education: Humanizing Focus for Educators", Journal of Career Development, June, Volume 3, 42-48. 1976

[15] Grawitch, M.J., Gottschalk, M., and Munz, D.C. "The Path to A Healthy Workplace: A Critical Review Linking Healthy Workplace Practices, Employee Well-Being, and Organizational Improvements", Consulting Psychology Journal: Practice and Research,Volume 58, Number 3, 129-147. 2006.

[16] Porter, A. C. "External Standards and Good Teaching: The Pros and Cons of Telling Teachers What to Do". Educational Evaluation and Policy Analysis, Volume 11, Number. 4, 343-356. 1989.

[17] Seniwoliba, A. J. Teacher motivation and job satisfaction in senior high schools in the Tamale metropolis of Ghana, Merit Research Journal of Education and Review, Vol. 1(9), 181-196, October, 2013.

[18] Filak V. F. and Sheldon K. M. "Student psychological need satisfaction and college teacher-Course evaluations”, Educational Psychology, Volume 23, Issue 3, 235-247. 2003.

[19] Tietjen, M. A. and Myers, R. M. "Motivation and Job Satisfaction”, Management Decision, Volume 36, Issue 4, pp. 226231. 1998.

[20] Leithwood, W. Teacher Working Conditions That Matter: Evidence for Change, Published by the Elementary Teachers' Federation of Ontario, 2006.

[21] Hanushek, Eric A, Susanne Link, and Ludger Woessmann "Does school autonomy make sense everywhere? Panel estimates from PISA", NBER Working Paper 17591. 2011.

[22] Hendayana, S., Supriatna, A., \& Imansyah, H. Indonesia's issues and challenges on quality improvement of mathematics and science education. Paper presented at the Africa-Asia University Dialogue for Educational Development: Efforts towards improving the quality of education. Avalaible from: http://aadcice.hiroshima-u.ac.jp/e/reseach/paper_no4-1.pdf.

[23] Daniel, E.G.S. "Asia Pacific Science Education in a Knowledge Society”, Asia Pacific Journal of Education, Volume 33, Number 2, 170-182, 2013. 
[24] Direktorat Pembinaan Pendidik dan Tenaga Kependidikan Pendidikan Menengah tahun 2012, Data Rekap Guru, Avalaible from: http://ptkdikmen.kemdiknas.go.id/content/data-rekap-guru.

[25] Asher, H. B. Causal Modeling. Beverly Hills, CA: Sage; 1983.
[26] Specht, D. A. “On the Evaluation of Causal Models.” Social Science Research, Volume 4, 113-133. 1975.

[27] Cranny, C. J., Smith, P. C., and Stone, E. F. Job Satisfaction: How People Feel about Their Jobs and How It Affects Their Performance, New York: Lexington Books. 1992. 